\title{
PARTISIPASI POLITIK MASYARAKAT DALAM PEMILIHAN UMUM TAHUN 2019 (Studi di Desa Langku-Langku Kecamatan Tiworo Tengah Kabupaten Muna Barat)
}

\author{
Wa Ode Siti Husmidar, Misran Safar, Andi Syahrir P \\ Jurusan Pendidikan Pancasila dan Kewarganegaraan \\ Fakultas Keguruan dan Ilmu Pendidikan \\ Universitas Halu Oleo \\ Email: tarsanasmara31@gmail.com, misransafar18@gmail.com \\ samiruddin@gmail.com
}

\begin{abstract}
Abstrak: Penelitian ini bertujuan (1) untuk mengetahui bentuk partisipasi politik masyarakat dalam pemilihan umum tahun 2019 dan (2) untuk mengetahui faktor-faktor yang mempengaruhi partisipasi politik masyarakat dalam pemilihan umum tahun $2019 \mathrm{di}$ Desa Langku-Langku Kecamatan Tiworo Tengah Kabupaten Muna Barat. Jenis penelitian yang digunakan adalah deskriptif dengan pendekatan kualitatif. Teknik pengumpulan data yakni penelitian kepustakaan (library research) dan penelitian lapangan (field research) yaitu wawancara dan dokumentasi. Jumlah responden dalam penelitian ini adalah 15 orang, dan informan yaitu, Kepala Desa, KPPS, PPS, dan tokoh masyarakat. Hasil penelitian menunjukkan bahwa (1) bentuk partisipasi politik masyarakat dalam pemilihan umum tahun 2019 di Desa Langku-Langku Kecamatan Tiworo Tengah Kabupaten Muna Barat masih rendah ini terlihat pada kegiatan kampanye, dan perhitungan suara di TPS. (2) faktor-faktor yang mempengaruhi partisipasi politik masyarakat yakni faktor ekonomi, faktor pendidikan, dan faktor lingkungan. Kesimpulan penelitian ini yaitu (1) bentuk partisipasi politik masyarakat dalam pemilihan umum tahun 2019 di Desa Langku-Langku Kecamatan Tiworo Tengah Kabupaten Muna Barat sangat rendah, indikasi rendahnya partisipasi ini ditujukan oleh rendahnya keikutsertaan mereka dalam setiapa tahapan pemilihan Legislatif dan Presiden dan Wakil Presiden. (2) faktor-faktor yang mempengaruhi partisipasi politik masyarakat dalam pemilihan Legislatif dan Presiden dan Wakil Presiden adalah faktor ekonomi, faktor pendidikan, dan faktor lingkungan.
\end{abstract}

\section{Kata Kunci: Partisipasi Politik Masyarakat, Faktor-Faktor yang Mempengaruhi Partisipasi}

\section{PENDAHULUAN}

Partisipasi politik dalam negara demokrasi merupakan indikator implementasi penyelenggaraan kekuasaan negara tertinggi dalam kedaulatan rakyat, yang dimanifestasikan keterlibatan mereka dalam pesta demokrasi (pemilu). Makin tinggi tingkat partisipasi politik mengindikasikan bahwa rakyat mengikuti dan memahami serta melibatkan diri dalam kegiatan kenegaraan, sebaliknya tingkat partisipasi politik yang rendah pada umumnya mengindikasiakan bahwa rakyat kurang menaruh apresiasi atau minat terhadap masalah kegiatan kenegaraan. Rendahnya tingkat partisipasi politik rakyat direfleksikan dalam sikap golongan putih (golput) dalam pemilu. Oleh karena itu, tingkat partisipasi masyarakat dalam pemilihan umum merupakan hal yang sangat penting, karena rendah atau tingginya suatu partisipaasi masyarakat merupakan indikator penting jalannya proses demokrasi dari kedaulatan rakyat.

Partisipasi politik merupakan salah satu aspek penting yang menentukan kualitas demokrasi suatu negara. Tingginya partisipasi menunjukkan bahwa warga masyarakat memahami dan antusias dalam kegiatan-kegiatan politik. Warga masyarakat yang ikut berpartisipasi dalam proses politik terdorong oleh keyakinan 
bahwa kegiatan mereka memiliki efek politik tersalurnya kepentingan atau setidaknya akan mempengaruhi kebijakan. Sehingga sosialisasi politik menjadi sangat penting untuk dilakukan untuk memberi pemahaman kepada masyarakat dan memunculkan kesadaran politik.

Pemilihan umum (pemilu) merupakan salah satu pilar demokrasi yang menempatkan masyarakat sebagai subyek dalam pelaksanaan demokrasi, sehingga pemilu menjadi kunci terciptanya demokrasi. Di Indonesia pemilu merupakan suatu wujud nyata dari demokrasi dan menjadi sarana bagi rakyat dalam menyatakan kedaulatannya terhadap negara dalam pemerintah, pemilu berlandaskan pancasila dan Undang-undang Dasar Negara Republik Indonesia tahun 1945. Pemilu diselenggarakan dengan asas langsung, umum, bebas, rahasia, jujur, dan adil dalam Negara Kesatuan Republik Indonesia (NKRI). Pemilihan umum tahun 2019 merupakan pemilu serentak pertama kali di Indonesia dan pengalaman pertama bagi partai politik, penyelenggara pemilu, dan masyarakat secara umum semenjak pemilu dilaksanakan di Indonesia. Artinya, bangsa Indonesia belum pernah memiliki pengalaman mengelola pemilihan Presiden, DPR, DPD, DPRD Provinsi dan DPRD Kabupaten/kota secara serentak.

Pemilihan umum dalam kehidupan berdemokrasi sebagai sarana pelaksanaan kedaulatan rakyat yang duduk diparlemen dan Presiden dan Wakil Presiden serta membentuk pemerintahan secara demokratis konstitusional. Partisipasi politik partai politik dalam semua langkah pemilihan umum serta kepercayaan masyarakat dalam proses pemilihan umum merupakan syarat penting bagi penyelenggaraan pemilihan umum yang berhasil dalam menjamin kelangsungan hidup berbangsa dan bernegara menuju cita-cita kemerdekaan. Pemilihan umum tidak sekedar pemilihan wakil-wakil rakyat untuk duduk di Dewan Perwakilan Rakyat, akan tetapi pemilihan umum menjadi sarana yang penggunaannya tidak boleh mengakibatkan rusaknya sendi-sendi demokrasi, tetapi harus menjamin pelaksanaan pancasila secara murni dan konsekuen.

Salah satu bentuk partisipasi politik masyarakat dalam pemerintahan yang demokratis adalah keikutsertaan anggota masyarakat dalam pemilihan umum, karena proses pemilihan umum merupakan salah satu bentuk partisipsi politik langsung dari rakyat. Dalam pelaksanaan pemilihan umum sangat dibutuhkan sistem politik dan biasanya untuk Negara-negara yang sedang berkembang, dimana sebagian besar rakyatnya belum memiliki kematangan yang cukup dalam berpolitik. Setiap masyarakat dari suatu negara memiliki budaya politik sendiri, demikian pula halnya dengan individu-individu yang hidup ditengah-tengah masyarakat memiliki orientasi maupun persepsi terhadap sistem politiknya.

Faktor yang mempengaruhi partisipasi politik seseorang ialah kesadaran politik yang merupakan kesadaran akan hak dan kewajiban sebagai warga negara. Hal ini menyangkut pengetahuan seseorang tentang lingkungan masyarakat dan politik, dan menyangkut minat dan perhatian seseorang terhadap lingkungan masyarakat dan politik tempat dia hidup. Serta kepercayaan kepada pemerintah merupakan penilaian masyarakat terhadap pemerintah, apakah masyarakat menilai pemerintah dapat dipercaya atau tidak. Apabila seseorang memiliki kesadaran politik dan kepercayaan kepada pemerintah yang tinggi maka partisipasi cenderung aktif. Sebaliknya, apabila kesadaran politik dan kepercayaan kepada pemerintah rendah maka partisipasi politik cenderung pasif (apatis). Partisipasi politik sangat 
berperan penting dalam terlaksananya kehidupan politik di lingkungan masyarakat. Karena Indonesia menganut sistem demokrasi sehingga keputusan yang diambil dalam pembuatan kebijakan ataupun pemilihan ditentukan berdasarkan rakyat. Dan hasil-hasil yang akan dicapai dipengaruhi oleh partisipasi masyarakat.

Desa Langku-Langku terletak di Kecamatan Tiworo Tengah Kabupaten Muna Barat dengan jumlah penduduk 599 jiwa, dimana mayoritas penduduknya bekerja sebagai petani tentu akan menghadapi berbagai kendala teknis baik karena pengalaman terhadap pendidikan, maupun aktifitas mereka dalam bidang pertanian demikian pada kegiatan pemilihan umum masyarakat diharapkan ikut terlibat dalam kegiatan pemilihan tersebut dan ikut dalam pengambilan keputusan serta ikut dalam memilih pemimpin yang sesuai dengan pilihannya.

\section{Bentuk-bentuk Partisipasi Politik}

Dalton (2009: 171) mengelompokkan bentuk partisipasi politik sebagai berikut:

a. Kegiatan kampanye (campaign activity) yaitu suatu aktivitas kampanye yang mewakili suatu bentuk-bentuk partisipasi yang merupakan suatu perluasan dari pemilihan (extension of electoral participation). Termasuk di dalamnya bekerja untuk partai ataupun seorang kandidat, demi menghadiri pertemuan kampanye, melakukan persuasi terhadap orang lain untuk memilih, dan segala bentuk aktivitas selama dan antara pemilihan.

b. Kegiatan diskusi politik (Communal activity) yaitu bentuk-bentuk dari partisipasi tersebut berbeda dengan aktivitas kampanye karena aktivitas komunal merupakan tempat di luar setting pemilihan. Termasuk dari keterlibatan dalam suatu kelompok masyarakat yang interest dan concern dengan kebijakan umum misalnya kelompok studi lingkungan, kelompok wanita, atuapun juga proteksi terhadap suatu konsumen.

c. Pemberian suara (voting) yakni bentuk partisipasi yang terkait dengan pemilihan. Voting merupakan bentuk paling sederhana untuk mengukur tingkat partisipasi.

Pendapat lain dikemukakan oleh Joyo, (2009:4) bahwa bentuk partisipasi nyata, meliputi:

a. Partisipasi uang adalah partisipasi untuk memperlancar usaha usaha bagi pencapaian kebutuhan masyarakat yang memerlukan bantuan

b. Partisipasi harta benda adalah partisipasi dalam bentuk menyumbang harta benda, biasanya berupa alat-alat kerja atau perkakas

c. Partisipasi tenaga adalah partisipasi yang diberikan dalam bentuk tenaga untuk pelaksanaan usaha-usaha yang dapat menunjang keberhasilan suatu program.

Menurut Sahid, (2011: 184) partisipasi politik mempunyai fungsi bagi kepentingan pemerintah meliputi:

a. Untuk mendorong program-program pemerintah. Hal ini berarti bahwa peran serta masyarakat diwujudkan untuk mendukung program politik dan program pemerintah

b. Sebagai institusi yang menyuarakan kepentingan masyarakat sebagai masukan bagi pemerintah dalam mengarahkan dan meningkatkan pembangunan

c. Sebagai sarana untuk memberikan masukan, saran dan kritik terhadap pemerintah dalam perencanaan dan pelaksanaan program-program pembangunan 


\section{Faktor-faktor yang Mempengaruhi Partisipasi Politik}

Faktor-faktor yang mempengaruhi partisipasi politik masyarakat menurut Huntington, (1992: 16-18) antara lain :

1. Faktor ekonomi, merupakan faktor yang mempengaruhi partisipasi politik masyarakat, jika kondisi ekonomi baik tentu partisipasi pada kegiatan politik akan tinggi dan bila ekonomi yang tidak baik tentu akan sangat berimplikasi pada kegiatan politk masyarakat, karena faktor ekonomi merupakan faktor penting untuk keberlangsungan hidup masyarakat.

2. Faktor pendidikan, merupakan salah satu modal potensial yang dimiliki oleh manusia, karena pendidikan merupakan salah satu unsur yang menunjang tujuan yang di capai dalam kegiatan politik

3. Faktor lingkungan, faktor lingkungn adalah kondisi atau keadaan dari kehidupan masyarakat dari berbagai kelompok, yang berlangsungnya berbagai kegiatan interaksi sosial antar berbagai kelompok masyarakat

Menurut Surbakti, (2006: 144) faktor-faktor yang mempengaruhi partisipasi politik adalah:

a. Kessadaran politik adalah kesadaran akan hak dan kewajiban sebagai warga negara hal ini menyangkut minat dan perhatian seseorang terhadap lingkungan dan politik tempat ia hidup. Hal ini menyangkut pengetahuan seseorang tentang lingkungan masyarakat dan politik, dan menyangkut minat dan perhatian seseorang terhadap lingkungan tempat dia hidup.

b. Kepercayaan terhadap pemerintah yaitu penilaian seseorang terhadap pemerintah apakah ia menilai pemerintah dapat dipercaya atau tidak. Apabila pemerintah sebelumnya dianggap tidak dapat mengakomodir aspirasi masyarakat, maka pada pemilihan politik selanjutnya akan mempengaruhi partisipasi politik masyarakat.

\section{METODE PENELITIAN}

\section{Lokasi dan Waktu Penelitian}

Tempat penelitian ini dilaksanakan di Desa Langku-langku, Kecamatan Tiworo Tengah Kabupaten Muna Barat. Alasan peneliti melakukan penelitian di Desa Langku-langku Kecamatan Tiworo Tengah Kabupaten Muna Barat) karena (1) letaknya sangat strategis, antara tempat peneliti berdomisili dengan lokasi penelitian, sehingga akan mempermudah peneliti dalam mengumpulkan data secara maksimal (2) peneliti ingin mengetahui tingkat partisipasi masyarakat dalam pemilihan umum Legislatif (DPRD Kabupaten Muna Barat) maupun Presiden dan Wakil Presiden yang dilakukan secara serentak. Waktu penelitian ini sudah dilaksanakan pada semester ganjil tahun pelajaran 2019/2020.

\section{Jenis Penelitian}

Jenis penelitian ini adalah penelitian deskriptif, dengan pendekatan kualitatif, dimana penelitian tersebut berusaha memberikan uraian serta gambaran yang sifatnya menjelaskan mengenai suatu objek yang diteliti secara sistematis dan aktual terkait fakta-fakta yang ada.

\section{Responden dan Informan}

Responden dalam penelitian ini adalah masyarakat wajib pilih, pada pemilihan Legislatif (DPRD Kabupaten Muna Barat) dan calon Presiden dan 
Wakil Presiden terkhusus di Desa Langku-Langku Kabupaten Muna Barat yang berjumlah 15 orang, yang dipilih dengan alasan bahwa mereka diidentifikasi secara acak sebagai masyarakat Desa Langku-Langku yang terdaftar sebagai masyarakat wajib pilih pada pemilihan Legislatif (DPRD Kabupaten Muna Barat) Presiden dan Wakil Presiden. Selain responden untuk memperoleh data yang akurat maka digunakan informan dalam penelitian ini terdiri dari: kepala desa, KPPS, PPS, dan tokoh masyarakat. Sehingga dapat memberikan data tentang partisipasi politik masyarakat pada pemilihan umum tahun 2019.

\section{Teknik Pengumpulan Data}

Dalam penelitian kualitatif ini, maka alat pengumpulan data yang digunakan adalah pedoman wawancara. Pedoman wawancara sebagai alat yang digunakan untuk mengadakan wawancara langsung dengan responden dan informan penelitian agar dapat memberikan penjelasan atau informasi yang berkaitan dengan pelaksanaan penelitian.

\section{Teknik Analisis Data}

Teknik analisis data yang digunakan dalam penelitian ini terdiri dari tiga alur kegiatan yang terjadi secara bersamaan yaitu:

1. Reduksi data diartikan sebagai proses pemilihan, sehingga diperoleh kesimpulan akhir untuk diverivikasi

2. Penyajian data untuk menemukan pola-pola yang bermakna serta memberikan kemungkinan adanya penarikan kesimpulan dan pengambilan tindakan

3. Menarik kesimpulan, membuat kesimpulan yang terbuka dan kemudian menjadi lebih spesifik.

\section{HASIL DAN PEMBAHASAN}

Bentuk Partisipasi Politik Masyarakat Dalam Pemilihan Umum Calon Anggota Legislatif (DPRD Kabupaten Muna Barat) dan Pemilihan Presiden dan Wakil Presiden

Bentuk partisipasi politik masyarakat pada pemilihan umum Legislatif (DPRD Kabupaten Muna Barat) dan pemilihan Presiden dan Wakil Presiden merupakan salah satu aktivitas politik yang dilakukan oleh masyarakat Desa Langku-Langku seperti: ikut dalam kegiatan kampanye, kegiatan diskusi politik, pemberian suara, serta menyaksikan perhitungan surat suara calon Legislatif (DPRD Kabupaten Muna Barat) pemilihan Presiden dan Wakil Presiden. Berikut ini merupakan bentuk partisipasi politik masyarakat Desa Langku-Langku Kecamatan Tiworo Tengah Kabupaten Muna Barat dalam pemilihan umum umum Legislatif (DPRD Kabupaten Muna Barat) dan Eksekutif Desa Langku-Langku Kecamatan Tiworo Tengah Kabupaten Muna Barat tahun 2019 yang dapat dilihat secara bertahap yaitu:

\section{a. Kegiatan kampanye Calon Anggota Legislatif (DPRD Kabupaten Muna Barat) Presiden dan Wakil Presiden}

Berdasarkan hasil penelitian dapat disimpulkan bahwa kegiatan kampanye telah diadakan di Desa Langku-Langku. Saat pelaksanaan kampanye banyak masyarakat yang tidak mengetahui kegiatan tersebut khususnya yang jaraknya jauh dari lapangan diadakanya kampanye. Sehingga banyak masyarakat Desa LangkuLangku yang tidak menghadiri kegiatan kampanye tersebut. Pada tahap kampanye Calon Legislatif (DPRD Kabupaten Muna Barat) tidak ada tahapan-tahapan khusus karena pada tahap ini masyarakat di Desa Langku-Langku hanya diinformasikan 
melalui undangan lisan atau tulisan tentang dilaksanakannya kegiatan kampanye calon Legislatif (DPRD Kabupaten Muna Barat) pada tempat dan waktu yang telah ditentukan. Jika dihubungkan dengan penelitian penulis, maka kegiatan kampanye yang diadakan di Desa Langku-Langku peneliti menggunakan teori dari Dalton (2009:171) kampanye merupakan suatu aktivitas kampanye yang mewakili suatu bentuk-bentuk partisipasi yang merupakan suatu perluasan dari pemilihan (extension of electoral participation). Termasuk di dalamnya bekerja untuk partai ataupun seorang kandidat, demi menghadiri pertemuan kampanye, melakukan persuasi terhadap orang lain untuk memilih, dan segala bentuk aktivitas selama dan antara pemilihan.

b. Diskusi kelompok Calon Anggota Legislatif (DPRD Kabupaten Muna Barat) dan Eksekutif Sulawesi Tenggara di Desa Langku-Langku Kecamatan Tiworo Tengah Kabupaten Muna Barat di TPS

Hasil penelitian dapat menunjukkan bahwa kegiatan kelompok sangat penting saat pemilihan umum khususnya pada pemilihan Legislatif (DPRD Kabupaten Muna Barat) karena pada saat pemilihan Legislatif banyak calon yang mencalonkan diri sehingga pemilih terkadang bingung untuk memilih calon mana yang pantas untuk menjabat. Sehingga dengan adanya kegiatan kelompok ini dapat di musyawarahkan bersama antar anggota masyarakat. Jika dihubungkan dengan penelitian penulis, maka kegiatan diskusi kelompok yang diadakan di Desa Langku-Langku peneliti menggunakan teori dari Dalton (2009:171) Kegiatan diskusi politik (Communal activity) yaitu bentuk-bentuk dari partisipasi tersebut berbeda dengan aktivitas kampanye karena aktivitas komunal merupakan tempat di luar setting pemilihan. Termasuk dari keterlibatan dalam suatu kelompok masyarakat yang interest dan concern dengan kebijakan umum misalnya kelompok studi lingkungan, kelompok wanita, atuapun juga proteksi terhadap suatu konsumen. Diskusi kelompok Legislatif (DPRD Kabupaten Muna Barat) dan Presiden dan Wakil Presiden merupakan salah satu cara yang dilakukan masyarakat dalam berkomunikasi dengan masyarakat lainnya, untuk menyampaikan pendapat, saran, maupun kritikan dengan tujuan untuk bisa menyamakna persepsi untuk mencapai tujuan bersama.

\section{c. Pemberian suara (voting) Calon Anggota Legislatif (DPRD Kabupaten Muna Barat) dan Eksekutif}

Hasil penelitian menunjukkan bahwa kegiatan pemungutan suara (voting) telah diadakan di Desa Langku-Langku. Saat pelaksanaan pemungutan suara masyarakat sangat antusias untuk berpartisipasi dalam memberikan hak pilihnya dalam pemilihan Legislatif (DPRD Kabupaten Muna Barat). Namun pada kasus yang terjadi di Desa Langku-Langku sebagian besar masyarakatnya mengalami kesulitan dan kebingungan pada saat melakukan pencoblosan surat suara dikarenakan surat suaranya terdiri dari lima kotak suara dan memakan waktu yang cukup lama. Partisipasi politik masyarakat dalam kegiatan pemberian suara, merupakan salah satu puncak kegiatan pesta demokrasi yang sangat dinantikan oleh seluruh masyarakatdan para kandidat khususnya calon Legislatif (DPRD Kabupaten Muna Barat). 
Faktor-faktor yang Mempengaruhi Partisipasi Masyarakat dalam Pemilihan Umum Legislatif (DPRD Kabupaten Muna Barat) Presiden dan Wakil Presiden Desa Langku-Langku Kecamatan Tiworo Tengah Kabupaten Muna Barat Tahun 2019

Faktor-faktor yang mempengaruhi partisipasi politik masyarakat Desa Langku-Langku Kecamatan Tiworo Tengah Kabupaten Muna Barat dalam pemilihan umum umum Legislatif (DPRD Kabupaten Muna Barat) dan Eksekutif Desa Langku-Langku Kecamatan Tiworo Tengah Kabupaten Muna Barat tahun 2019 yang dapat dikelompokkan menjadi beberapa bagian yaitu:

\section{Faktor ekonomi}

Faktor ekonomi merupakan faktor yang mempengaruhi partisipasi politik masyarakat di Desa Langku-Langku, karena kondisi kehidupan ekonomi masyarakat Desa Langku-Langku yang cukup memprihatinkan jika ekonomi baik tentu partisipasi pada kegiatan politik akan tinggi dan dan bila ekonomi yang tidak baik tentu akan sangat berimplikasi pada rendahnya partisipasi masyarakat pada kegiatan politik, hal ini disebabkan karena masyarakat mau menerima uang dari para calon Legislatif demi untuk keberlangsungan hidup masyarakat Desa LangkuLangku. Dalam kegiatan politik tentu membutuhkan kecukupan ekonomi sehingga bisa berpartisipasi secara aktif untuk melakukan aktivitas dalam tahapan-tahapan kegiatan politik calon Legislatif. Jika dihubungkan dengan penelitian penulis, maka faktor ekonomi, yang diadakan di Desa Langku-Langku peneliti menggunakan teori dari Huntington, (1992: 16-18) merupakan faktor yang mempengaruhi partisipasi politik masyarakat, jika kondisi ekonomi baik tentu partisipasi pada kegiatan politik akan tinggi dan bila ekonomi yang tidak baik tentu akan sangat berimplikasi pada kegiatan politk masyarakat, karena faktor ekonomi merupakan faktor penting untuk keberlangsungan hidup masyarakat.

\section{Faktor Pendidikan}

Pendidikan merupakan salah satu salah satu modal potensial yang dimiliki oleh manusia karena pendidikan itu akan eksis ketika diaplikasikan kedalam kehidupan nyata dan termasuk ikut dalam kegiatan partisipasi politik. Semakin tinggi pendidikan seseorang, maka semakin tajam pula seseorang dalam menganalisa informasi tentang politik dan persoalan-persoalan sosial yang diterima semakin meningkat dan menciptakan minat dan kemampuannya dalam berpolitik. Jika dihubungkan dengan penelitian penulis, maka faktor pendidikan yang telah diteliti di Desa Langku-Langku peneliti menggunakan teori dari Huntington, (1992: 16-18) faktor pendidikan, merupakan salah satu modal potensial yang dimiliki oleh manusia, karena pendidikan merupakan salah satu unsur yang menunjang tujuan yang di capai dalam kegiatan politik.

\section{Faktor lingkungan}

Faktor lingkungan merupakan interaksi antara masyarakat dengan lingkungan, ataupun lingkungan yang juga terdiri dari makhluk sosial atau manusia. Faktor lingkungan inilah yang kemudian membentuk suatu sistem pergaulan yang memiliki peranan besar di dalam membentuk sebuah kepribadian seseorang, dan kemudian terjadilah sebuah interaksi diantara orang atau juga masyarakat dengan lingkungannya. Sehingga faktor lingkungan menjadi salah satu faktor tingginya partisipasi politik masyarakat dalam pemilihan umum Legislatif, dan Eksekutif. Hal ini disebabkan karena masyarakat memilih calon Legislatif dan Eksekutif tidak di pengaruhi oleh lingkungan tetangga mereka. Mereka memilih 
calon Legislatif dan Eksekutif tanpa pengaruh dari lingkungan tetangga setempat, akan tetapi mereka menggunakan hak pilih mereka berdasarkan hati nurani masing-masing tanpa adanya paksaan dari luar. Dengan tingginya partisipasi masyarakat akan menjadi salah satu faktor pendorong dan pendukung partisipasi politik masyarakat Desa Langku-Langku. Jika dihubungkan dengan penelitian penulis, maka faktor lingkungan yang telah diteliti di Desa Langku-Langku peneliti menggunakan teori dari Huntington, (1992: 16-18) faktor lingkungan merupakan kondisi atau keadaan dari kehidupan masyarakat dari berbagai kelompok, yang berlangsungnya berbagai kegiatan interaksi sosial antar berbagai kelompok masyarakat.

\section{PENUTUP}

\section{Kesimpulan}

1. Bentuk partisipasi politik masyarakat dalam pelaksanaan pemilihan umum Legislatif (DPRD Kabupaten Muna Barat) dan pemilihan umum Presiden dan Wakil Presiden di Desa Langku-Langku adalah dengan melakukan kegiatan kampanye, diskusi politik, pemberian suara dan penghitungan surat suara.

2. Faktor-faktor yang mempengaruhi partisipasi politik dalam penelitian ini meliputi: (1) faktor ekonomi, tingkat pendapatan dalam masyarakat Desa Langku-Langku (2) faktor pendidikan, tingkat pendidikan formal dalam masyarakat (3) faktor lingkungan, semangat masyarakat untuk ikut serta dalam pemilihan umum legislatif maupan Presiden dan Wakil Presiden.

\section{Saran}

1. Masyarakat wajib pilih, harus lebih meningkatkan dalam memahami sosialisasi politik seperti memahami fungsi, serta visi misi agar dalam pemilihan masyarakat tidak salah dalam menentukan pilihannya.

2. Pemerintah sebaiknya membangun kepercayaan kepada masyarakat dan merealisasikan akan janji yang diutarakan, karena hal ini sangat berpengaruh pada tingkat partisipasi politik masyarakat agar bisa berpartisipasi secara aktif dan terencana dalam kegiatan politik.

\section{Daftar Pustaka}

Dalton. 2009. Comparative Politics. New York: Person Longman

Huntington. 1992. Partisipasi Politik di Negara Berkembang. Jakarta: Rineka Cipta

Joyo, Hami. 2009. Beberapa catatan tentang partisipasi masyarakat.

Jakarta: Departemen pendidikan dan kebudayaan

Sahid, Komarudin. 2011. Memahami Sosiologi Politik. Bogor. Ghalia Indonesia

Surbakti, Ramlan. 2006. Memahami Ilmu Politik. Jakarta: Gramedia Widiasarana Indonesia. 